\title{
Design and construction of a prototype for the launch and recovery of a "SAAB SEAEYE FALCON" ROV for the diving and salvage department of the Colombian Navy
}

Diseño y construcción de un prototipo para el lanzamiento y recuperación de un ROV Tipo "SAAB SEAEYE FALCON" para el departamento de buceo y salvamento de la Armada Nacional de Colombia

DOI: https://doi.org/10.25043/19098642.188

\begin{abstract}
The divers of the Colombian Navy carry out search and salvage operations of equipment that are submerged in maritime or fluvial areas. To be effective, the diving and salvage department must have appropriate equipment to ensure the completion of the inspections carried out; however, since underwater dive inspections are carried out in difficult access or dangerous places, it is necessary to use specialized equipment such as remote operation vehicles - ROV, where the urgent need to implement a launching system for the immersion and subsequent extraction of such equipment is identified.

As a result of the existing problem, the project is built with the purpose of creating a prototype for the immersion and extraction of a "SAAB SEAEYE FALCON" ROV, thus facilitating inspections and reaching depths of 300 meters. For its construction, exploratory research was carried out and a deductive method was applied; modeling was performed using SolidWorks software as a tool for its construction that allowed identifying the best electromechanical structure, and the component to be used for its construction was identified through the study of pure and composite materials, which processes allowed designing and building a LARS prototype that met the operational objectives for which it was proposed.
\end{abstract}

Jeison Rojas Rua ${ }^{1}$

Hector Iván Sánchez Mateus ${ }^{2}$

Wilson Ovalle Porras ${ }^{3}$

Lissette Casadiego ${ }^{4}$

Key words: Diver, Launch, Lars (launch and recovery system for ROV), Recovery, ROV (remote operation vehicle).

\section{Resumen}

Los buzos de la Armada Nacional de Colombia desarrollan operaciones de búsqueda y rescate de equipos que se encuentran sumergidos en zonas marítimas o fluviales, y para su efectividad el departamento de buceo y salvamento debe contar con los equipos correspondientes que garanticen el funcionamiento de las inspecciones realizadas; sin embargo, al desarrollarse inmersiones de inspecciones subacuáticas en lugares de difícil acceso o peligrosos, es necesario usar equipos especializados como el vehículo de operación remota - ROV, donde se identifica la necesidad apremiante de implementar un sistema de lanzamiento para su inmersión y posterior extracción.

Como resultado de la problemática existente, el proyecto se construye con el objetivo de crear un prototipo para la inmersión y extracción de un ROV tipo "SAAB SEAEYE FALCON" facilitando las inspecciones y alcanzando a llegar a 300 metros de profundidad. Para su ejecución se realizó investigación exploratoria y método deductivo; como herramienta para su construcción se realizaron modelaciones a través del software SolidWorks que permitieron identificar la mejor estructura electromecánica y mediante un estudio de materiales puros y compuestos se identificó el componente a usarse para su construcción, procesos que permitieron diseñar y construir un prototipo LARS, que cumplió con los objetivos operacionales para los cuales fue proyectado.

Palabras claves: Buzo, Lanzamiento, Lars (sistema de lanzamiento y recuperación para el Rov), Recuperación, Rov (vehículo de operación remoto).

Date Received: January 15 2019 - Fecha de recepción: Enero 15 de 2019

Date Accepted: May 20 2019 - Fecha de aceptación: Mayo 20 de 2019

\footnotetext{
${ }^{1}$ Escuela de Buceo y Salvamento. Cartagena, Colombia. Email: jeison.rojas.ru@armada.mil.co

${ }^{2}$ Escuela de Buceo y Salvamento. Cartagena, Colombia. Email: Hector.sanchez.ma@armada.mil.co

${ }^{3}$ Jefatura de Formación, Instrucción y Educación Naval. Bogotá, Colombia. Email: wilson.ovalle@armada.mil.co

${ }^{4}$ Escuela Naval de Suboficiales "ARC Barranquilla”. Barranquilla, Colombia. Lissette.casadiego@armada.mil.co
} 


\section{Introduction}

An underwater inspection is an activity in which the conditions of a place, vessel or structure submerged in an aquatic environment are verified. Over time, this type of activity, which was initially carried out only by specialized divers, has been evolving with the development of new technologies, such as underwater cameras and the use of remotely operated vehicles (increasingly with greater capabilities). It must be taken into account that a series of tools or systems are required for the effective operation of this type of equipment, in order to carry out the immersion, deployment, recovery, extraction, and the fixed umbilical administration, launch and recovery systems of the submarine vehicle.

Based on the above, the research has been based on the characteristics required for a launch and recovery system that can be adapted to the vessels of the Colombian Navy, such as frigates or pilot, which is characterized by its versatility, easy transportation and handling in the operations and inspections carried out by the Diving and Salvage Department. Additionally, it contributed to the generation of knowledge in the "Diving equipment" research line is geared towards the field of underwater inspections carried out by the divers of the Colombian Navy.

The mission of the Diving and Salvage Department of the Colombian Navy includes the following operations: underwater inspections, maintenance operations, maritime salvage and assistance, which purpose is to recover and/or prevent the loss of afloat units, aircraft, war and quartermaster materials; which is why the divers of the entity are constantly performing underwater operations of this nature.

Some ROV launch and recovery systems available in the market

These types of systems can be found in different models and there are companies such as Saab Seaeye and Rolls Royce that manufacture them; such equipment operate with a hydraulic system that allows moving the arm from its resting position to its working position and provides the load capacity, it also has an electrical system that consists of a gearmotor that moves ROV up and down; the materials with which such equipment are manufactured must be exposed to load resistance tests and a previous use study.

For the design of the prototype launch and recovery system, the model must be adapted to the needs and characteristics of the afloat units of the Colombian Navy, which include the following:

Fig. 1. Saab Seaeye Launch \& Recovery Systems.

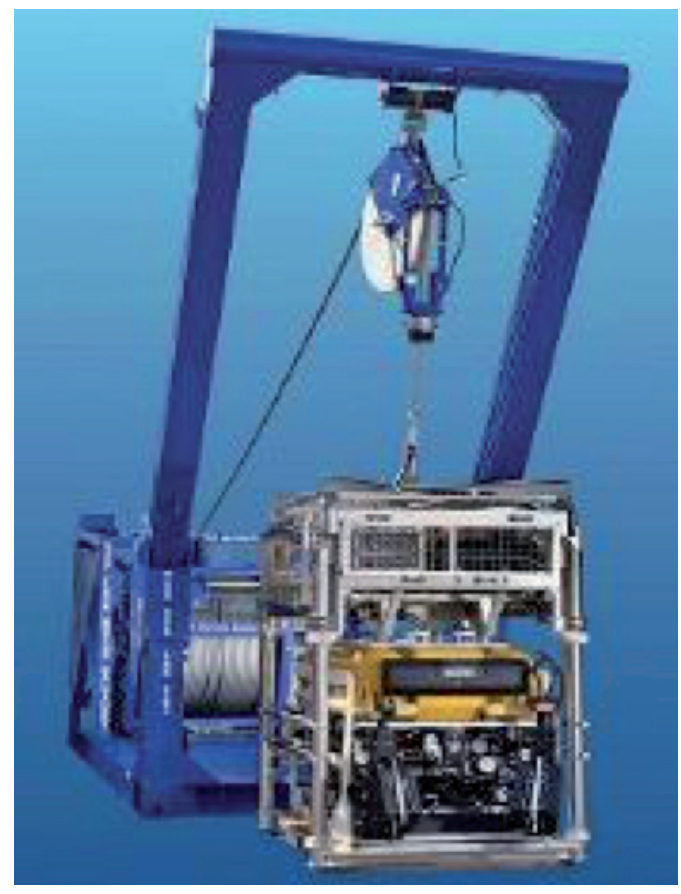

Fig. 2. Saab Seaeye Launch \& Recovery Systems.

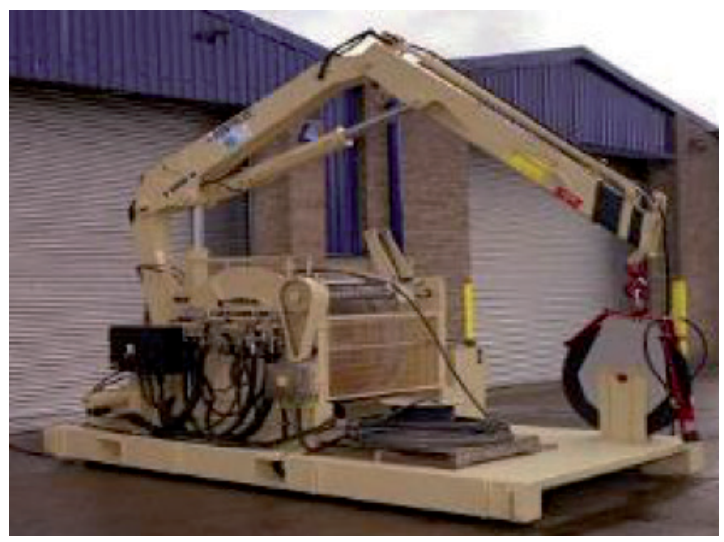

Source: SAAB SEAEYE LTD. ALL RIGHTS RESERVED [Consulted on 03-30-2018]; [online] https://bit.ly/2GGuRMh 
Determination of the technical specifications required for the prototype ROV immersion and extraction system

The Diving and Salvage Department identified the need to have a system for the immersion and extraction of ROVs with the following characteristics: high tensile strength and rated strength; it must be capable of being disassembled to facilitate transport; it must have the ability to be attached to the roof of frigate units such as the ARC "ANTIOQUIA" and Pilot units such as the ARC "ISLA TESORO"; it must have a mechanical source for the lowering and hoisting of the ROV, easy maintenance, affordable spare parts in the local market, low costs and its operation must requires little personnel participating in the maneuver without affecting the safety of operators and the equipment.

The technical specifications that the prototype must have are indicated below:

Material strength: Taking into account that the ROV has a weight of $78 \mathrm{~kg}$, a safety factor of 3 was considered, equivalent to a load of $234 \mathrm{~kg}$. The material with which the structure was built has technical characteristics that provide a tensile strength of $400 \mathrm{Mpa}$ and a yield strength of $317 \mathrm{Mpa}$.

Electric motor: The motor must have at least $1 / 4$ horsepower, providing the necessary torque to move the structure for the operation of the ROV. The proposed engine has an input of $1700 \mathrm{rpm}$ with a
40:01 gearbox and uses a crown worm, which works as a brake in case of loss of electrical power or when disengaging. It has a $110 \mathrm{~V}$ AC power supply which provides greater ease when powering it up (which is voltage mostly used in afloat units and portable power plants used in the Colombian Navy).

Design of the prototype using 3D modeling software for the ROV immersion and extraction system according to the operation and use needs of the equipment

For the design of the prototype, it was necessary to makefield visits to the Frigate "ARCANTIOQUIA" and "ARC ISLA TESORO", taking measurements and identifying the place where the system could be used.

After determining that the useful space for the prototype was insufficient, since there were more deck fixtures such as bitts, cleats, eyebolts and heavy armament, with a space on the port side of $110 \mathrm{~cm}$ wide aft to the bow, which is arranged for the location of the gate while at the dock, and from the rail to the amidship line there is a space of 350 $\mathrm{cm}$ using one of the eyebolts to fix the structure to the roof.

The modeling market was verified for this type of systems that allowed contributing to the investigation of the prototype proposed and giving way to the design of the device. SolidWorks software was used for building a 3D model taking into account the needs and characteristics that

Table 1. Material Comparison Table.

\begin{tabular}{|c|c|c|c|}
\hline \multicolumn{4}{|c|}{ COMPARATIVE TABLE } \\
\hline Item & Characteristics & Carbon Steel & Galvanized Steel \\
\hline 1 & Square Tube & YES & YES \\
\hline 2 & Outer Measurements & $2 " \times 2 "$ & $2 " \times 2 "$ \\
\hline 3 & Thickness & $2.5 \mathrm{~mm}$ & $2.5 \mathrm{~mm}$ \\
\hline 4 & Yield Stress & $3522 \mathrm{Kg} / \mathrm{cm}^{2}$ & $3522 \mathrm{Kg} / \mathrm{cm}^{2}$ \\
\hline 5 & Breaking Strength & $4348 \mathrm{Kg} / \mathrm{cm}^{2}$ & $4348 \mathrm{Kg} / \mathrm{cm}^{2}$ \\
\hline 6 & Corrosion Resistance & $\mathrm{NO}$ & YES \\
\hline 7 & $\begin{array}{l}\text { Cost (in dollars) for } 6 \\
\text { meters }\end{array}$ & $\$ 21.95$ & $\$ 48.07$ \\
\hline
\end{tabular}

Source: Authors. 
were sought, in which procedure new ideas were identified that allowed favoring the prototype and ensuring a more reliable and secure system.

Construction of the prototype using the technical specifications for the "SAAB SEAEYES FALCON" ROV immersion and extraction system

For the construction of the prototype, the space available on the vessels was first taken into account, followed by the selection of the material with which the structure was built, comparing the prices and durability of carbon steel with and without galvanized coating. Carbon steel was chosen without galvanized coating, since its durability depends on the maintenance of the structure and its price is lower in relation to carbon steel with galvanized coating, and they have the same yield stress and breaking strength properties.

After having selected the material and built the structure, the free body diagram was then made.

Fig. 3. Free Body Diagram.

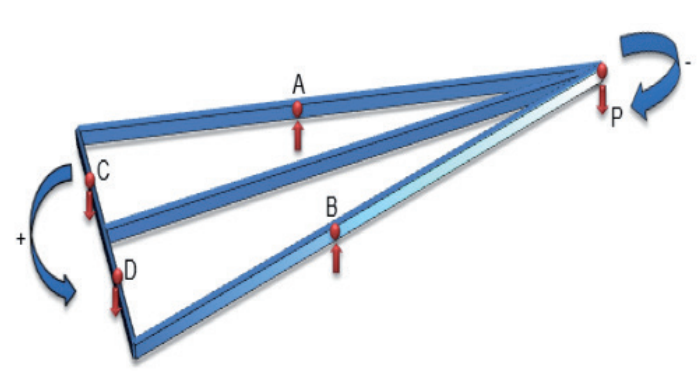

Source: Authors.

Fig. 4. Dimensions and Measurements.

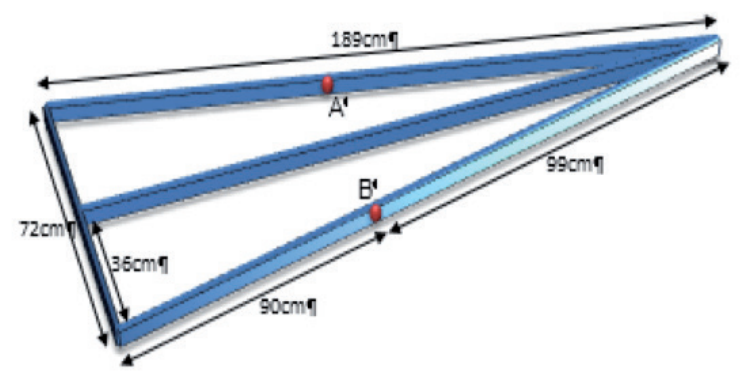

Source: Authors.
Once determined the dimensions, distances and forces at play on the piece, the reactions at $\mathrm{C}$ and $\mathrm{D}$ were calculated at the time of suspending a load equal to the ROV with a mass of $80 \mathrm{~kg}$.

Since the sum of momentums is equal to 0 .

$$
\begin{aligned}
& M=F^{*} D \\
& \quad \sum M=0 ; \\
& \quad-P(99 \mathrm{~cm})+D(90 \mathrm{~cm})+C(90 \mathrm{~cm})=0
\end{aligned}
$$

By symmetry, it is established that the forces present at point $\mathrm{C}$ are equal to the forces at point D.

$$
\begin{aligned}
& F_{C}=F_{D} ; \\
& -P(99 \mathrm{~cm})+2 D(90 \mathrm{~cm})=0
\end{aligned}
$$

$P=m g$

$$
D=\frac{P(99 \mathrm{~cm})}{2(90 \mathrm{~cm})}
$$

$$
m=m g
$$

$$
D=\frac{m g(99 \mathrm{~cm})}{180 \mathrm{~cm}}
$$

$g=10 \mathrm{~m} / \mathrm{s}^{2}$

$$
D=\frac{80 \mathrm{~kg} * 10 \mathrm{~m} / \mathrm{s}^{2}(99 \mathrm{~cm})}{180 \mathrm{~cm}}
$$

$$
D=\frac{79200 \mathrm{Ncm}}{180 \mathrm{~cm}}
$$

$$
D=440 N
$$

Knowing what the forces are at points $D, C$ and $P$ at the time of suspending a load of $80 \mathrm{~kg}$, the forces on the $Y$ axis were added to calculate the forces on the vertical axis at points $A$ and $B$, which are the most vulnerable points of the structure.

$\sum F y=0 ;$ 


$$
-C-D-P+B y+A y=0
$$

By symmetry, it was established that the forces present at point $B$ are equal to the forces at point $A$.

$$
\begin{aligned}
& B y=A y ; \\
& -C-D-P+2 B y=0 \\
& B y=\frac{C+D+P}{2} \\
& B y=\frac{440 N+440 N+800 N}{2} \\
& B y=\frac{1680 N}{2} \\
& B y=840 N
\end{aligned}
$$

The momentum that the force $P$ produces at point $A$ and $B$ is found when a weight of $80 \mathrm{~kg}$ is suspended. By symmetry, it was considered that the momentum is the same in both points.

$$
\begin{aligned}
& M_{B}=P(99 \mathrm{~cm}) \\
& M_{B}=800 N(99 \mathrm{~cm}) \\
& M_{B}=79200 N \mathrm{~cm}
\end{aligned}
$$

Taking into account the physical properties of the square carbon steel tube of 2"x 2" provided by the supplier according to the technical sheet, the strength of the material was calculated to verify that it meets the safety characteristics.

Moment of Inertia (I) $=16.94 \mathrm{~cm}^{4}$

$\sigma$ Strength $=4368 \mathrm{~kg} / \mathrm{cm}^{2}$

$\sigma$ Yield $=3522 \mathrm{~kg} / \mathrm{cm}^{2}$

Then the allowable stress was determined according to the safety factor of 3 used.

$F S=3$;
Fig. 5. Physical Characteristics of the Material.

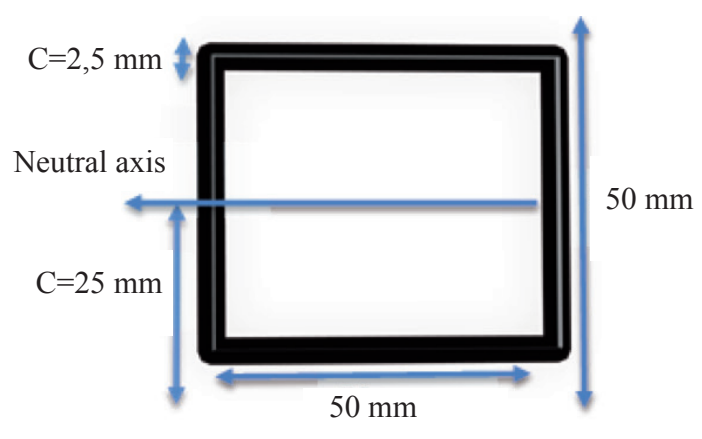

Source: Authors.

$\begin{aligned} \sigma_{\text {Perm }} & =\frac{\sigma_{\text {Ultimo }}}{F S} \\ \sigma_{\text {Perm }} & =\frac{4368 \mathrm{~kg} / \mathrm{cm}^{2}}{3}\end{aligned}$

$\sigma_{\text {Perm }}=1456 \mathrm{~kg} / \mathrm{cm}^{2}$

The above shows that the allowable stress is less than the yield stress, allowing the tube to remain in the elastic range to work safely.

With the information provided by the supplier and the parameters established for this type of work, the calculation was made to find the bending moment of the tube.

$$
\begin{aligned}
& \sigma_{\text {Perm }}=\frac{M f * C}{I} \\
& M f=\frac{\sigma_{\text {Perm }} * I}{C} \\
& M f=\frac{4368 \mathrm{~kg} / \mathrm{cm}^{2} * 16,94 \mathrm{~cm}^{4}}{2,5 \mathrm{~cm}} \\
& M f=9865.85 \mathrm{kgcm} \\
& M=M f * g \\
& M=9865.85 \mathrm{kgcm} * 10 \mathrm{~m} / \mathrm{s}^{2} \\
& M=98658.56 \mathrm{Ncm}
\end{aligned}
$$


To find the maximum momentum to which the structure can be subject with such safety factor, the bending moment was multiplied by gravity and it was determined that $M=98658.56 \mathrm{Ncm}>M B=$ $79200 \mathrm{Ncm}$, which is the momentum produced by the $80 \mathrm{~kg}$ load, which means that it is much higher and the structure can work safely.

However, it was decided to calculate what would be the maximum load that could be supported by the structure with the established allowable stress, and what would be the limit load for the breaking point of the structure, based on the previous data.

The momentums on the piece were added considering that points $C$ and $D$ have the same momentum and that points $A$ and $B$ are subject to the same stress.

$$
\begin{aligned}
M_{C} & =M_{D} ; \\
& -P(99 \mathrm{~cm})+2 D(90)=0 \\
M_{D} & =98658.56 \mathrm{Ncm} ; \\
& -P(99 \mathrm{~cm})+2(98658.56 \mathrm{Ncm})=0 \\
& -P(99 \mathrm{~cm})+197317.12 \mathrm{Ncm}=0 \\
P & =\frac{197317.12 \mathrm{Ncm}}{99 \mathrm{~cm}} \\
P & =1993.1 \mathrm{Ncm} \\
P & =m g ; \\
m & =\frac{P}{g} \\
P & =\frac{1993.1 \mathrm{kgm} / \mathrm{s}^{2}}{10 \mathrm{~m} / \mathrm{s}^{2}} \\
m & =199,31 \mathrm{~kg}
\end{aligned}
$$

$$
\sigma_{\text {Strength }}=4368 \mathrm{~kg} / \mathrm{cm}^{2}
$$$$
M f=\frac{4368 \mathrm{~kg} / \mathrm{cm}^{2} * 16,94 \mathrm{~cm}^{4}}{2,5 \mathrm{~cm}}
$$

$C=2,5 \mathrm{~cm}$

$$
M f=29597.56 \mathrm{kgcm}
$$$$
M=M f * g
$$$$
M=9865.85 \mathrm{kgcm} * 10 \mathrm{~m} / \mathrm{s}^{2}
$$$$
M=295975.68 \mathrm{Ncm}
$$

$$
\begin{aligned}
M_{D} & =295975.68 \mathrm{Ncm} ; \\
& -P(99 \mathrm{~cm})+2(295975.68 \mathrm{Ncm})=0 \\
- & P(99 \mathrm{~cm})+591951.36 \mathrm{Ncm}=0 \\
P & =\frac{591951.36 \mathrm{Ncm}}{99 \mathrm{~cm}} \\
P & =5979.3 \mathrm{~N} \\
P & =m g ; \\
m & =\frac{P}{\mathrm{~g}} \\
m & =\frac{5979.3 \mathrm{kgm} / \mathrm{s}^{2}}{10 \mathrm{~m} / \mathrm{s}^{2}} \\
m & =597.93 \mathrm{~kg}
\end{aligned}
$$


The previous calculation allows establishing the breaking mass of the most vulnerable piece of the structure and ensuring the work with the ROV with the allowable stress and the safety factor of 3 .

Based on the above calculations, the materials were quoted again, choosing $2 \times 2$-inch square carbon steel tubes for the framework of the structure. The first thing that was built was the structure of the arms that would be responsible for lifting and lowering the ROV, taking into account that it should be versatile and disassemblable. Cuts were made at $45^{\circ}$, $13^{\circ}$ and $90^{\circ}$ on the tubes to shape the structure.

\section{Conclusions}

When the characteristics of the prototype were assessed and the study of loads to which the device would be subject was commenced, it was possible to identify that the strength, versatility, easy transportation, easy operation, disassemblable structure and ease of use in the vessels mentioned above were some of the criteria to be taken into account at the time of designing and building the prototype ROV launch and recovery system.

It was possible to identify the possible designs according to the characteristics established.

A first prototype was developed in the construction stage, but it was observed that the system was too robust and it was decided to focus the project on the construction of the following design in order

Fig. 6. Prototype tests.

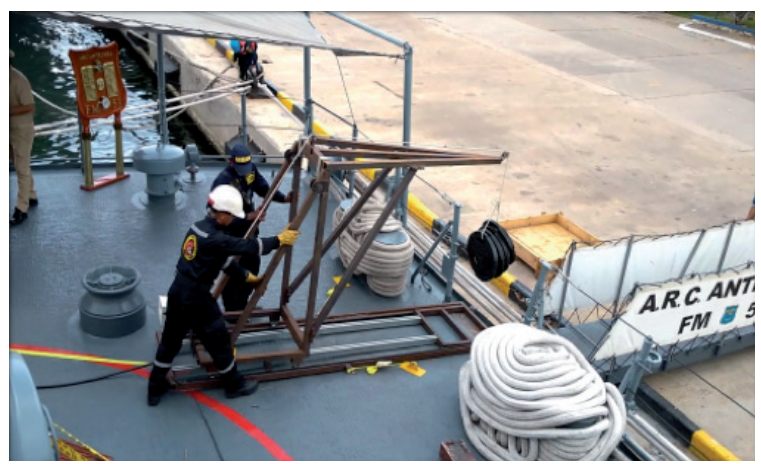

to ensure that the requirements established at the onset were fulfilled and that the prototype would be used in future operations with the ROV, thus facilitating and ensuring the work of the personnel.

\section{Bibliography}

CÁTEDRA CALCULO DE ELEMENTOS DE MAQUINAS. [On line]. Available on internet: http://www3.fi.mdp.edu.ar/emaquinas/files/ presenta__reductores.pdf.

CORREA Julio, VÁSQUEZ Rafael, RAMÍREZ Juan, TABORDA Elkin, ZULUAGA Carlos, POSADA Norha, LONDOÑO Jorge. Una arquitectura para el diseño conceptual de vehículos para exploración subacuática.

ELEMENTOS DE MAQUINAS. Desmontaje de elementos de máquinas. [On line]. Available on internet: http://repositorio.sena.edu.co/sitios/ elementos_maquinas /vol1/pdf/1-desmontajede-elementos-de-maquinas.pdf.

ELEMENTOS DE MAQUINAS. Mantenimiento de reductores de velocidad. [On line]. Available on internet: http://repositorio.sena.edu.co/ sitios/elementos_maquinas/vol14/volumen 14 . html.

MECÁNICA DE ESTRUCTURAS. Libro 1 resistencia de materiales. [On line]. Available on internet: http://cervera.rmee.upc.edu/ libros/Mec\%C3\%A1nica_de_estructuras_I_ Resistencia_de_Materiales.pdf.

MOTORES ELÉCTRICOS. [On line]. Available on internet: http://biblio3.url.edu.gt/ Libros/2013/ing/pim/12.pdf.

RESISTENCIA DE MATERIALES BÁSICOS PARA ESTUDIANTES DE INGENIERÍA. [On line]. Available on internet: http:// www.bdigital.unal.edu.co/5855/1/ jorgeeduardosalazartrujillo20072_Parte1.pdf.

Source: Authors. 
ROLLS ROYCE LTD. Our history. [On line]. TECNOLOGÍA. Engranajes. [On line]. Available Available on internet: https://www.rolls-royce. com/about/our-history.aspx. on internet: http://www.areatecnologia.com/ mecanismos/engranajes.html.

SAAB SEAEYE LTD. Saab Seaeye Profile. [On line]. Available on internet: http://www.seaeye. TECNOLOGÍA INDUSTRIAL. ES; resistencia com/company.html. de los materiales [On line]; Available on internet: http://www.tecnologia-industrial.es/ Resistencia\%20de\%20los\%20materiales.htm. 